\title{
Entrevista com Peter Fry
}

ENTREVISTADORAS

Daniela do Amaral Alfonsi

Íris Morais AraúJo

Lílian SALES

RACHEL RuA BAPTISTA

Rafaela de Andrade Deiab
COLABORADOR

Prof. Dr. Júlio Assis Simóes
Antropólogo formado em Cambridge, Peter Fry fez sua primeira pesquisa de campo nos anos 1960 entre os Zezuru da Rodésia do Sul (atual Zimbábue), ligado à Universidade de Londres e a sua associada na África, a University College of Rhodesia and Nyasaland. Defendido seu doutorado, Fry veio para o Brasil em 1970, onde ajudou a fundar a UNICAMP e se integrou à vida acadêmica local, pesquisando no país temas relacionados a relações raciais, homossexualidade e religiáo. Entre 1989 e 1993, retornou à África como representante adjunto da Fundação Ford e, de volta ao Brasil, passou a integrar o corpo docente da UFRJ, onde permanece até hoje. Sua produção mais recente concentra-se no campo das discussóes sobre sexualidade e na análise das conseqüências da utilização de categorias como raça, diversidade e outras, correntes no métier antropológico, nas políticas públicas para a população negra implementadas nos últimos anos. Textos sobre este assunto foram reunidos em $A$ persistência da raça, ${ }^{1}$ livro que nos serviu de mote para a realização desta entrevista realizada em 24 de agosto de 2005, em Campinas, que discorre sobre muitos pontos polêmicos e revela uma profunda fidelidade do antropólogo a certos pressupostos de nossa disciplina.

1. FRY, Peter. 2005. A persistência da raça: ensaios antropológicos sobre o Brasil e a África Austral. Rio de Janeiro: Civilização Brasileira.
CC: No início de $A$ persistência da raça, o senhor recupera sua formação profissional e expóe uma tensão entre duas correntes teóricas presente em seu primeiro trabalho de campo. Ela seria entre a Escola de Cambridge, onde estudou, e a de Manchester, presente na University College of Rhodesia and Nyasaland, onde foi pesquisar. O senhor poderia aprofundar as questóes levantadas por essa tensão e explicitar em que pontos cada uma dessas escolas foram importantes para sua formação?

PF: A antropologia que eu estudei durante a graduação era absolutamente clássica. Meu orientador era o Jack Goody e em Cambridge eram todos africanistas, com exceçáo do Edmund Leach. Ele representava nesse departamento o início do estruturalismo; o restante dos professores era estrutural-funcionalista. Como ainda não havia mestrado lá, fui, depois de me formar, trabalhar em Londres. Jack Goody sugeriu que eu fizesse uma pesquisa de campo mesmo sem nenhum treinamento, já que a graduação era totalmente teórica. Sempre tive muita dificuldade de imaginar como seriam na realidade aqueles conceitos que aprendíamos: linhagem mínima, linhagem máxima etc.; nunca consegui visualizar nada disso. Concorri, então, a uma bolsa e fui estudar na África, na antiga Rodésia do Sul. Uma das razóes pelas quais concorri a uma vaga naquele departamento é que Jack Goody disse que ele era muito bom. 
Naquela época, a Universidade de Londres estabeleceu filiais em vários lugares e um deles era a Rodésia do Sul: era a derradeira tentativa de assegurar o poderio branco naquela zona. A Universidade era muito nova e bem planejada e era o único lugar onde negros, mulatos e brancos conviviam. O chefe de departamento era o Clyde Mitchell, antigo colaborador de Max Gluckman que, na época, era professor em Manchester. Outra pessoa de muito destaque era o Jaap van Velsen, uma figura muito interessante, holandês, membro da Resistência na Segunda Guerra Mundial, aluno do Gluckman que fez pesquisa em Niassalândia (atual Malavi) entre os tonga. Mitchell e outros alunos de Gluckman, ao invés de fazerem estudos tradicionais, rurais, começaram a fazer antropologia urbana, predominantemente nas cidades de Zâmbia (antiga Rodésia do Norte). A questão que guiava esse grupo não era tentar destrinchar a lógica de sociedades tradicionais, mas ver e analisar a situação urbana nascida e caracterizada pela imigração da mão-de-obra rural para as cidades. Na época, havia uma teoria muito parecida com as teorias de aculturação daqui do Brasil, cuja idéia principal era a de que as pessoas sairiam de suas sociedades tradicionais e se aculturariam no processo de imigração. O pessoal do Gluckman não adotou essa teoria e isso em grande parte por causa dos primeiros trabalhos dele na África do Sul. No ensaio seminal "Análise de uma situação social na Zululândia moderna", ${ }^{2}$ do início da década de 1940, ele desenvolve o conceito de situação social. $\mathrm{O}$ argumento seria que a interpretação das sociedades passa pela análise de situaçóes sociais concretas. No que diz respeito à mudança sociocultural, criticava-se a no-

2. GLUCKMAN, Max. [1940-1958]. “Análise de uma situação social na Zululândia moderna”. In FELDMAN-BIANCO, Bela (org.). Antropologia das sociedades contemporâneas: métodos. São Paulo: Global, 1987. ção de "encontro de culturas" (culture contact) para pensar no encontro de agentes em situações concretas. Evidentemente, eles agiriam de acordo com suas tradiçôes, mas também de acordo com as suas avaliações sobre aquela situação. Então, toda essa antropologia eliminou do vocabulário as idéias de destribalização, aculturação etc., e olhava para o indivíduo como quase um manipulador, estrategista. Às vezes, eu penso criticamente que esse indivíduo era visto como uma espécie de homo universal, um indivíduo universal e racional. Mas eu penso isso agora, em retrospecto. Para a época, era muito importante frisar justamente esse aspecto racional e moderno para contrariar aquela posiçáo que dizia que os africanos não deveriam votar, não poderiam participar por serem destituídos da rational choice. $\mathrm{Ou}$ seja, essa perspectiva era adotada também por razóes políticas: a nossa preocupação era resgatar os negros africanos da pecha de tradição, de obscurantismo etc. Assim, quando cheguei à Rodésia do Sul, entrei em contato com o Jaap van Velsen que, evidentemente, achou que eu era um produto típico da classe média protegida britânica que precisava de um banho de realidade, e acusou o pessoal de Cambrigde de náo abrir os olhos para o que estava acontecendo no mundo. Ele me deu para ler o artigo de Gluckman sobre a Zululândia e um outro trabalho do Mitchell chamado "A dança kalela", que trata da relaçáo das várias etnias entre si e a relação delas com o poder branco nas fábricas e nas minas de Zâmbia. De fato, o argumento do Gluckman era que a antropologia tradicional era demasiadamente formal: ela elegia modelos que eram desenvolvidos pelos antropólogos, que em

3. MITCHELL, James Clyde. 1956. "The kalela dance: Aspects of social relationships among urban Africans in Northern Rhodesia”. Manchester: Manchester University Press (The Rhodes-Livingstone Institute Papers, 27). Disponível em: www.era.anthropology. ac.uk/Kalela. 
seguida traziam o seu material de campo apenas para ilustrá-los. Para Gluckman, o material de campo deveria ter primazia: sempre voltavam a Malinowski, porque todos concordavam que este antropólogo apresentava tantos dados que era possível inclusive discordar de sua análise. Então, a justificativa disso era que, se o antropólogo apresentasse uma massa de dados e depois a sua interpretação, evidentemente o leitor teria liberdade de discordar e reinterpretar. Um outro argumento, mais marxista, era de que qualquer situaçáo conteria dentro de si todas as contradiçóes da sociedade como um todo. Para estudar a sociedade, então, estudam-se as situaçóes. Mas também acho que tem mais uma questão da qual eles não falavam, e quem me alertou para isso foi o Carlos Vogt. Trata-se do que ele chamou de truque de escrita: começa-se com uma situação, o que é muito conveniente porque normalmente ela tem início, meio e fim; é linear. E a grande dificuldade da antropologia, creio eu, é que como tudo se relaciona a tudo, é muito difícil estabelecer prioridades, sobretudo saber por onde começar a escrever. A situação é um truque de escrita, porque ela dá a oportunidade de apresentar ao leitor algo que, de fato, é uma narrativa. Eu continuo a defender esse partido teórico porque ainda acredito nele. Nessa perspectiva, que também é meio goffmaneana, o ator é visto com múltiplos papéis e não há tanta preocupação com identidade, já que o ator assumiria suas identidades de acordo com as situaçóes - isso é muito pós-moderno, avant la lettre, mesmo que os pós-modernos náo reconheçam. Era, assim, uma atitude anti-culturalista, no sentido de não atribuir nada à cultura reificada, mas somente às relaçóes sociais. Isso vinha, evidentemente, de uma herança da Antropologia Social Britânica, da idéia de que se olha para o sistema de relaçóes sociais na sua totalidade, e não apenas para um conjunto de relaçóes qualquer. Tinha como herança a primazia do concreto, que talvez seja criticável hoje em dia, mas que é um bom ponto de partida, pelo menos. Além disso, a observaçáo participante foi exacerbada ao extremo pela Escola de Manchester. Não se tinha que ficar lá vestido de roupas coloniais e com tenda de etnógrafo tipo Malinowski, não... Tinha que realmente entrar em campo. Eles acreditavam nessa possibilidade e insistiram nela: cada vez que eu saía do meu campo e voltava para a Universidade, recebia olhares muito desconfiados. Eu comprei essa idéia totalmente; durante dois anos e meio vivi bem com os meus vizinhos, e isso era incomum, eu acho. Ou seja, essa tensão entre perspectivas teóricas não era muito séria de fato, porque não se negava a velha antropologia, mas se cobrava uma maior atenção para o presente, para a mudança e para a não-reificação da cultura.

CC: $\mathrm{O}$ senhor desenvolveu sua pesquisa no período de descolonização da África. Em que medida a observação participante se relacionava a algum tipo de envolvimento político na luta anti-colonialista?

PF: Eram coisas diferentes. A gente tinha, e até hoje tem, uma atitude totalmente anti-racista e anti-raça. Evidentemente, as nossas simpatias estavam com o movimento de libertação. Mas vejam bem: a atitude náo era exatamente de interferência. O Jaap van Velsen me pegou pelo colarinho, me colocou contra a parede e disse assim: "Você vai se simpatizar muito com esses movimentos, mas você não vai fazer parte. Você não é de lá, você não é negro, você não é africano, você é um quase proto-intelectual antropólogo. Se você quer influenciar a situação você vai conversar com os seus pares, você vai escrever para eles e esperar que aquilo que você escreveu influencie desta forma nos resultados políticos”. Foi um conselho que levei muito a sério. Mais tarde percebi a ironia da situação: meses depois eu vi o professor holandês em sua 
sala recebendo uma liderança do movimento estudantil e ensinando-lhe instruçóes de como fazer política universitária. Mais tarde ainda, fui descobrir que ele fazia parte de um movimento de guerrilha urbana que, depois da independência unilateral liderada por Ian Smith na Rodésia do Sul, ${ }^{4}$ importava granadas, pois achavam que pequenas intervençôes a bomba seriam o estopim da revoluçáo. Mas ele foi expulso do país antes da polícia descobrir o seu papel. Com relaçáo à política, existia o agravante de haver dois partidos nacionalistas negros que se degladiavam. $\mathrm{O}$ perigo para os negros era tanto entre os negros quanto que entre os brancos, o que convinha muito ao poder branco, evidentemente, porque os negros se destruíam. A minha pesquisa de campo teve que ser cuidadosamente negociada com as autoridades governamentais, os velhos chefes, e as novas lideranças políticas. Era uma situação muito difícil de negociar porque era bastante inédito um jovem antropólogo branco viver com os africanos nas suas aldeias. Era necessária a autorizaçáo do poder público e o Comissário do Distrito me olhava com bastante desconfiança, todo mundo me olhava com desconfiança. Porém, eu não podia me queixar, ninguém tinha me convidado, estava lá por minha vontade apenas. Mas que foi uma situação muito difícil foi, e muito difícil de fazer pesquisa também.

CC: Como a sua pesquisa se desenvolveu entáo?

PF: A proposta original era fazer um estudo sobre migração de mão-de-obra: minha idéia era passar um ano nesta aldeia e depois

4. Mesmo sem o reconhecimento da Grã-Bretanha, em 1965 Ian Smith tornou-se primeiro ministro da Rodésia do Sul, garantindo o poderio branco na região através de um regime de apartheid, que perdurou até 1980. Somente nessa data que este país foi reconhecido como independente. um ano na cidade, bem na linha da Escola de Manchester. Mas não consegui as informaçôes necessárias com os trabalhadores, sobre renda, por exemplo, porque eles eram muito desconfiados. Ao mesmo tempo, apesar de o Jaap van Velsen me instruir a não entrar no tema da religião, este assunto foi ficando para mim cada vez mais fascinante. Van Velsen tinha razáo porque, de fato, quase todo mundo queria estudar religiáo entre os shona, já que era um sistema bastante complexo. Além disso, havia uma fascinaçáo por possessão pelos espíritos, pois na Inglaterra não existia esse tipo de crença. Mas, para fazer a pesquisa, contratei um professor primário como intérprete e guia. Eu trabalhava em sua aldeia e morava na casa de sua irmã. Lá pelas tantas, ele começou a desenvolver uma série de alergias em relaçáo a comidas e bebidas. Começou com a cerveja local, produzida pelas pessoas de lá. Esses encontros com cerveja são os mais ideais para a pesquisa, porque está todo mundo presente e a conversa flui. Então, o que eu mais fazia era ficar tomando cerveja e ouvindo conversas. Meu intérprete começou a não suportar sequer seu cheiro. Eu ficava com algumas pessoas tomando uma cerveja e ele ficava longe de mim. Depois, ele começou a náo poder comer mais a comida básica de lá, que é uma espécie de polenta de milho. Ele só podia comer um outro grăo nativo chamado rapoko (painço, em português), que produz muito pouco e é muito trabalhoso para moer. Entáo, começamos uma via-crucis para tentar descobrir as razóes disso tudo, e o que foi revelado é que ele estaria sendo escolhido pelos espíritos para ser um médium. Nesse processo, eu fui vendo que várias pessoas da geraçáo dele, de vinte $\mathrm{e}$ poucos anos, estavam seguindo exatamente $o$ mesmo caminho. Já tinham saído os primeiros resultados da pesquisa do grande historiador Terence Ranger (o livro maravilhoso dele que se chama Revolt in Southern Rhodesia 1896-7: 
A Study in African Resistance, ${ }^{5}$ saiu logo em seguida) que é sobre a rebelião dos negros contra os brancos em 1896. Os brancos do Cecil Rhodes $^{6}$ chegaram em 1890 , e em 1896, apenas seis anos depois, houve uma revolta coordenada em vários lugares do país. Ninguém conseguiu entender tal articulação porque não havia governos centralizados no norte. Descobriram, no final, que foram os médiuns que organizaram a rebelião, porque eles mantinham uma rede de comunicação que perpassava as fronteiras políticas territoriais. Eu pensei: "É isso que está acontecendo aqui. Estou vendo o repeteco dessa mesma situação". Ficava cada vez mais claro que aqueles jovens estavam em um processo de rejeição da religião cristã; para eles, Jesus Cristo era apenas um profeta ou um antepassado dos brancos, não dos negros, e que eles tinham de voltar para os seus antepassados, e náo para os antepassados dos brancos. Essa idéia estava intimamente ligada à mensagem política, uma espécie de nacionalismo cultural. Quando voltei para a Universidade, disse a Van Velsen: "Isso está acontecendo na minha frente e náo posso evitar de escrever sobre isso". Assim, escrevi sobre religião em um contexto contemporâneo de luta política. Depois saiu um segundo livro de outro antropólogo, David Lan, ${ }^{7}$ confirmando tudo que eu suspeitava: de fato, essa rede de comunicação entre os médiuns era utilizada para coordenar a guerrilha que eclodiu no norte do país depois da minha volta para a Inglaterra.

CC: O senhor fala de sua experiência na África e como ela influenciou, em um primeiro

5. RANGER, Terence O. 1967. Revolt in Southern Rhodesia 1896-7: A Study in African Resistance. London: Heinemann.

6. Político e empresário, Rhodes é considerado o fundador da Rodésia.

7. LAN, David. 1985. Guns \& Rain: Guerrillas \& Spirit Mediums in Zimbabwe. Harare: Zimbabwe $\mathrm{Pu}$ blishing House. momento, sua percepção das relaçóes raciais no Brasil. Num segundo momento, mostra como sua experiência no Brasil o fez repensar sua interpretação sobre as relações raciais na África. $\mathrm{O}$ que a sua formação e atuação nos centros acadêmicos africanos e brasileiros contribuíram para a sua reflexão sobre questóes raciais no Brasil e na África? Quais seriam, nessa perspectiva, os rendimentos de uma antropologia comparativa?

PF: Não são apenas experiências em departamentos, são experiências de vida. Ao chegar ao Brasil, o que mais me chamou a atenção, depois da África e da Inglaterra, era a ideologia de náo-racismo; eu nunca tinha encontrado um país com esse tipo de ideologia e achei muito positivo. Também fiquei impressionado com a homogeneidade cultural, com o fato de todo mundo, independentemente da aparência física, falar a mesma língua, comer a mesma feijoada, beber a mesma caipirinha, crer nos mesmos espíritos etc. Mesmo as religióes chamadas afro-brasileiras não eram de africanos, nem de negros, eram de todos. Isso está nas obras de Bastide, mas eu não imaginava. Tanto é que, quando comecei a estudar a umbanda, achava que ela ia ser parecida com o que tinha estudado na África, que ia ser uma espécie de resistência, e eu vi o contrário, era uma religiáo absolutamente integrada ao tecido social brasileiro porque náo dizia sobre relaçóes de classe e muito menos sobre relaçóes de raça. No Brasil, as crenças básicas são muito parecidas e pesquisas de opinião pública revelam isso, inclusive. Elas variam um pouco por classe social, mas muito pouco por regiáo e muito menos por cor auto-atribuída. Porém, como digo no livro, era óbvio que alguma coisa não estava legal: ao mesmo tempo que não havia nenhum sinal de racismo aberto, quase todos os negros eram pobres. Eu tinha lido o Gilberto Freyre do luso-tropicalismo, seus livros que traziam 
essa ideologia para sustentar a manutençáo do poder branco na África, mas não Casa-grande \& Senzala. Quando o li, o fiz desconfiado. Era a época de discutir a democracia racial como ideologia e então parecia que, de fato, essa idéia era um engodo, uma máscara. Era essa a minha posição. Quando fui para a África pela segunda vez, em 1989, nove anos depois da independência de Zimbábue, a primeira sensação foi de euforia por estar de volta. Estava muito curioso e queria rever os meus amigos. Mas, no fundo, foi uma sensação de profunda tristeza. Uma de minhas idéias era tentar reescrever a história daquele lugar nos dez anos após a independência, mas desisti; era uma história absolutamente não-contável. Isso me fez repensar muita coisa. Descobri, por exemplo, que um grande amigo meu, chamado Nestor, foi morto nas últimas semanas da guerra civil. Acusado de ter sido traidor, foi ao tribunal sem defesa e acabou queimado vivo em um saco de fertilizantes. Percebi que a primeira eleição de Zimbábue não era uma eleição como se imagina, com eleitores mais ou menos livres para escolher, porque náo era uma questão de escolha eleitoral, mas sim de medo: o exército que mais amedrontava ganhou. Mas o mais grave é que o país não tinha superado as premissas do racismo. Os brancos que lá ficaram, os meus amigos, às vezes velhos amigos, viviam achando que estava tudo uma maravilha: na casa deles havia sempre um, dois, três, quatro ou cinco africanos, mas era uma espécie de cota, uma coisa forçada, que não tinha nenhuma espontaneidade. Os únicos lugares onde as pessoas comiam juntas eram naqueles almoços tipo business lunch, em que havia homens de negócios comendo juntos. Mas à noite ainda havia os restaurantes de branco e de negro, tudo continuava igual. Quando o Robert Mugabe ${ }^{8}$ começou a invocar a "nossa cultura", vi todas as premissas e pressupostos

8. Presidente do Zimbábue desde 1980. explícitos do racismo colonial reelaborados em um outro contexto, mas com exatamente a mesma função, de associar a raça à cultura e usá-la como arma política. Por isso, eu achava que o Zimbábue estava nos grilhóes de um pensamento racializado, o que prejudicaria tudo. Quando eu desci pela primeira vez em Maputo, em Moçambique, vi o contrário. Era o finalzinho do período socialista, não havia nada nas lojas e apenas um restaurante; tudo estava caindo aos pedaços, era impressionante. Mas fui muito bem recebido pelos intelectuais de lá, na posição de funcionário da Fundação Ford. Convidaram-me para visitar as suas casas (isso nunca acontecia em Zimbábue), onde, falando português, comendo bife e batata frita e tomando vinho, conheci uma elite cosmopolita que gostava das mesmas coisas de que eu gosto. E lá, como cá, todo mundo é cientista político e técnico de futebol, quer dizer, a conversa é muito gostosa e com as mesmas ironias daqui. O Samora Machel $^{9}$ era absoluta e visceralmente anti-tribalista e anti-racista. Os últimos anos do Império português tinham sido menos agressivamente racistas do que os anos anteriores, então Moçambique viveu um período de relativo não-racismo. Evidentemente, eu me lembrei do Brasil, porque tudo combinava: nos três lugares (Brasil, Zimbábue e Moçambique) os brancos eram dominantes, a distribuição de riqueza e da educação era muito parecida, com exceção que os dois países africanos tinham uma pequena elite de negros com um grau de escolaridade muito alto. Mas o que mais me chamou a atenção em Moçambique é que as relações entre africanos e europeus e o que eles chamam de mistos (porque são várias misturas em Moçambique devido ao fluxo de pessoas da Europa e do subcontinente indiano) náo eram caracterizadas pela desconfiança. Muitos racistas mais veementes devem ter saído de lá

9. Primeiro presidente de Moçambique, Machel governou este país entre 1975 e 1986. 
em 1975, possibilitando uma situaçáo relativamente relaxada, e eu pessoalmente me senti muito mais à vontade naquele ambiente do que em Zimbábue. Com isso, comecei a fazer uma crítica dos pressupostos do colonialismo britânico que nunca havia feito antes. E pensei: "Meu Deus, talvez o Gilberto Freyre ao menos tivesse razáo quando reconhecia dois estilos de colonização" e que certamente a maneira pela qual se compreende as diferenças não é a mesma em Zimbábue e nesses países (Moçambique e Brasil). A mudança de perspectiva na análise foi uma combinação não tanto pelo que eu li, mas pela experiência pessoal mesmo. Foi uma experiência comparativa; penso que a melhor maneira de estranhar qualquer instituição é ter o conhecimento de outra, de uma sociedade em relação a outra, pessoal ou através dos livros. Certamente foram aquelas experiências de Zimbábue e Moçambique que me chamaram a atenção para essas questóes. Foram experiências existenciais, de distanciamento de viver. Eu ansiava voltar para Moçambique o tempo todo. E o interessante é que este país agora cresce $12 \%$ ao ano, enquanto Zimbábue decresce $20 \%$ ao dia! Moçambique vai de vento em popa; com o final do socialismo se liberou uma energia reprimida muito positiva. E não é um país de ranço. Tem dificuldades inter-étnicas, inter-raciais, claro que tem, todo lugar do mundo tem, mas não são empecilhos, e penso que lá as pessoas sabem conviver.

CC: Ainda sobre este assunto, como a sua experiência como representante adjunto da Fundação Ford o ajudou a pensar sobre as relaçóes inter-raciais nos países de colonização inglesa e portuguesa?

PF: A Fundação Ford é americana e bastante racializada, então a minha experiência naquele escritório foi fundamental. Eu tinha um companheiro de trabalho, Michael Chege, negro africano do Quênia, que se tornou um grande amigo. De vez em quando vinham pessoas da América do Norte, e eu nunca vou esquecer o dia que chegou um negro americano que só falava com o Michael, chamando-o de brother. Eu estava me sentindo cada vez mais incomodado e, evidentemente, o Michael percebeu. Depois de um tempo ele se virou para o outro e disse: "Escuta, você está me chamando de brother. Eu não sou o seu irmão. Se você está usando este termo metaforicamente, o Peter é muito mais o meu irmáo do que você”. O Michael também tinha esse ódio da racialização das relações sociais. Tivemos muitas experiências, desmascarando e ridicularizando os novos racismos. Uma vez, em Dar-es-Salaam, na Tanzânia, encontramos um médico que morava em Washington, que começou a me xingar pela minha responsabilidade como um inglês por ter destruído as casas arredondadas da sua tribo e tê-los obrigado a fazer casas quadradas. $\mathrm{Eu}$ disse assim: "Desculpe, não estive lá na época, e realmente não me sinto responsável por isso". Mas Michael foi muito mais além: "Senhor médico, você mora aonde?". "Washington". "E... qual é o formato da sua casa?". Enfim, o que me chamava a atenção era a nocividade, a mentira, a hipocrisia dessas posiçóes completamente alucinadas que se produzem quando se racializa as situaçóes, mesmo as mais próximas. A própria Fundação Ford foi obsessivamente dividindo o mundo entre mulheres e homens, negros e brancos etc., então se começa a não ver mais nada, só essas categorias. Este não é o mundo que eu quero para mim. Por isso comecei a pensar que a idéia de uma sociedade sem raça é uma idéia legal, que náo é uma idéia maluca, e finalmente percebi que o inimigo era o racismo, e não a democracia racial. Eu gostava de ser inimigo do racismo, mas não inimigo da idéia do não-racismo. Passei a argumentar que a idéia da insignificância social da raça produz, e não mascara apenas, um tipo de relação social 
e certas situaçóes que deveriam ser compreendidas. Ou seja, não é uma ideologia, é um mito no sentido antropológico do termo; é um guia para a ação social, bem malinowskiano mesmo. Assim, entrei na contra-corrente dos meus velhos amigos. Por isso, não consigo assinar embaixo de uma reengenharia social que fortalece aquilo no qual discordo e tenho a mesma ojeriza que tenho para com a acusação de bruxaria, por exemplo. Porque aliás, bruxaria e racismo são casos muito parecidos.

CC: O senhor trabalha em seu livro com a idéia de democracia racial a partir de três formas. A primeira é como falsidade, aquilo que encoberta uma realidade social. A outra, mais ligada à antropologia britânica, é como um modo de justificar contradiçóes postas por um grupo social. E a terceira é como utopia, um ideal a ser alcançado. Gostaríamos que o senhor relacionasse um pouco mais essas três idéias.

PF: A segunda forma tem a ver com a terceira, e é baseada em toda aquela mudança da antropologia nas décadas de 1960 e 1970, quando se quebra com o estrutural-funcionalismo e com a relação direta que ele faz entre as relaçóes sociais e as representaçóes (a infra-estrutura e super-estrutura dos marxistas, mais ou menos). Tudo começa a ficar no mesmo plano analítico quando se percebe as interaçóes entre representaçóes, ação e prática. Quem ajudou muito foi Michel Foucault. Eu nunca consigo vê-lo como arauto do pós-modernismo, sempre o vi como um antropólogo olhando para a história. A idéia da positividade do discurso era muito importante; por isso, eu acho que se náo tivesse existido esse discurso da democracia racial, certas situaçóes seriam impossíveis, como o futebol, o carnaval etc. Quando meus amigos sul-africanos vêm aqui, eles não acreditam: eles acham que foi forjado, porque lá eles têm de forjar. No entanto, esse mito concorre com outro - o da inferioridade africana - que produz a situaçáo de desigualdade e um certo apartheid que se vê sobretudo nos mercados imobiliário e de trabalho. Acho que esses dois mitos produzem a situação contraditória em que a gente vive. Mas é necessário entender os dois; só um é complicado. A terceira forma de entender a idéia de democracia racial é a que diz qual é o caminho pela frente, ou seja, é evidentemente atacar o segundo mito e enaltecer o primeiro. Este mito, então, se torna utopia; o outro, por sua vez, tem de ser demonizado.

CC: No livro, o senhor trabalha com três conceitos-chaves. O primeiro é o de diversidade como conceito nativo, mas importado das naçóes anglo-saxás especialmente via agências de fomento à pesquisa. $\mathrm{O}$ segundo é o de mestiçagem, mistura ou cadinho como categoria cultural existente no Brasil. O terceiro é o de sincretismo e híbrido, que seria um conceito analítico do pesquisador. Cada uma dessas categorias revela reflexóes diferentes, mas que têm como questão de fundo uma tensão entre cultura nacional homogênea e cultura nacional segregada. É possível, então, falar de cultura nacional em termos analíticos, sem correr o risco de essencializar essa categoria?

PF: Se a gente for ver a constituição das burguesias nacionais na Europa, elas se construíram como cosmopolitas, incentivando, incitando e produzindo diversidade cultural local. As naçóes metropolitanas aplicavam esse conceito de diversidade em suas colônias, os ingleses mais que os portugueses. Se é confrontado o modelo de assimilação contra o de segregação, de fato, os portugueses eram muito mais assimilacionistas que os ingleses. Isso não quer dizer que os portugueses também não fossem segregacionistas, ou não incitassem certa diversidade. Mas o resultado desses processos 
é o apartheid por um lado e talvez, por outro, Moçambique. Essa idéia de diversidade, então, é produzida emicamente, como também a idéia de cultura nacional. Existem esses dois modelos; eles coexistem e produzem situaçóes, mas penso que, nessa oscilação - e estou sendo leacheano comigo mesmo -, a predominância de um sobre o outro tende a produzir o que chamamos de realidades nacionais. Não se trata de essencializar, mas o fato é que quando se sai do Brasil, sabe-se que se sai do Brasil.

CC: Por que se sai de uma cultura homogênea?

PF: Não totalmente homogênea, mas que tem qualquer coisa que eu sei, e que chamo de Brasil. Mas como vamos falar disso sem essencializar? Não sei, não sei mesmo. É verdade que as explicaçóes culturalistas no Brasil são muito complicadas, afirma-se que "o Brasil é assim, assim e assado". A palavra "é", em português, não é o inglês "is", porque no português ela se contrapóe ao "está", o que torna tudo muito mais estático. Sobre essa questáo de híbrido e sincrético serem analíticos, não sei... São e não são. Sincretismo é mais usado no campo religioso, aparece o tempo todo e pressupóe, logicamente, a existência de algo puro em algum momento, o que náo se pode acreditar. Então, a própria noção de sincrético eu acho que é mais êmica, mais nativa que analítica. Porque as pessoas falam assim. É uma maneira de tentar descrever, de colocar em palavras aquilo que as pessoas dizem, mas eu acho que são palavras pobres. Híbrido é também muito pobre, eu acho, por causa da sua própria etimologia: aquilo que é híbrido é infértil, não tem futuro. Logo, eu acho que não são conceitos muito úteis, apesar de saber que estáo muito em voga, porque entram na linguagem acadêmica e dos projetos políticos. O Brasil, na propaganda que se faz lá fora, especialmente nesse
"Ano do Brasil na França", fala de híbrido, de um país maluco e pós-moderno; são esses os termos usados. Eu acho que são idéias nativas mesmo, que vale a pena entender como elas entram em circulação. Mas no Brasil há os dois: o elogio da mistura - e isso é muito arraigado - e também a idéia de autenticidade presente, por exemplo, no candomblé, onde se produz cada vez mais África. Por isso se tem, quase leachanamente, os gumsa e gumlao oscilando e interagindo. Para mostrar como essa idéia da mistura está internalizada nos indivíduos, vou falar da pesquisa que estamos fazendo em escolas do Rio de Janeiro. Ao invés de perguntar às pessoas a raça/cor tal como o IBGE faz, a gente formulou assim: "Você sabe que o Brasil foi povoado pelos ameríndios, pelos europeus e pelos africanos. Em que proporção você acha que tem essas três ascendências?” Nenhum aluno respondeu evocando apenas uma única ascendência. Eu escrevi que sou 100\% europeu, mas ninguém colocou 100\% europeu, africano ou ameríndio. Os que se diziam pardos afirmavam que eram mais ou menos 1/3, 1/3, 1/3. Ou seja, eles reproduziram a idéia de mistura, o que, aliás, confirma a minha prática em sala de aula. Eu sempre pergunto isso para as pessoas, e aquelas que têm mais variedade são as mais orgulhosas, sobretudo as que dizem ter índio e africano. Elas sorriem de complacência, enquanto os puramente poloneses sofrem horrores...

CC: Hoje percebemos uma tendência à reificação da idéia de tradição por parte de grupos políticos e agências financiadoras, tornando-a um valor. Pede-se aos antropólogos definiçóes de cultura tradicional para a implementação de políticas públicas. Como o senhor se posiciona diante dessa situação?

PF: Há um movimento mesmo, nesse sentido. Fica mais claro em alguns lugares do que 
em outros, como na produçáo da indianidade e nos quilombos. Eu fico estarrecido diante de tudo isso, porque se fala agora de quilombos como se fossem lugares completamente diferentes do resto do Brasil. Isso me chama muito a atenção, porque quando o Carlos Vogt e eu fizemos a nossa pesquisa sobre o Cafundó, ${ }^{10}$ escrevemos sobre isso, e é como se não tivéssemos escrito. Eu lamento que a gente escreva, escreva, escreva e o discurso não mude. Fomos para o Cafundó porque lá tinha um vocabulário de origem africana; isso é verdade. Fora disso, culturalmente, era absolutamente igual a qualquer bairro rural pobre paulista, que já foi bastante estudado e sobre o qual muito se escreveu. Quando fomos atrás dessa língua que nunca mais achamos, fomos a dezenas de comunidades rurais negras onde as pessoas diziam que tinham essa língua, mas não tinham. Então, o pressuposto hoje é que quilombo é um lugar completamente distinto, o que náo vi quando o pesquisei.

CC: Com o argumento forte, também, que são formados por descendentes de escravos. Procura-se buscar em documentos essa comprovação...

PF: Não é mais necessário comprovar nada em princípio porque o decreto presidencial 4.887, de 20 de novembro de 2003, que rege a matéria, diz claramente que são os próprios quilombolas que se definem como tal. Não é necessário demonstrar nada em princípio, embora antropólogos são chamados para participar no processo de titulaçáo das terras. Ao mesmo tempo começam a existir políticas públicas para garantir a manutenção e a tradição dos quilombos. O projeto de Rafael Sanzio Araújo dos Anjos, chefe do Departamento de

10. Cf. VOGT, Carlos \& FRY, Peter. 1996. Cafundó, a Africa no Brasil: linguagem e sociedade. Campinas/ São Paulo: Ed. Unicamp/Companhia das Letras.
Geografia da Universidade de Brasília, diz assim: "Nós temos que ter políticas públicas nos quilombos, evitando que os jovens saiam, porque se os jovens saem vão perder a tradição". Isso foi exatamente a política do apartheid, que confinou as pessoas nas suas tradiçóes. Quer dizer, para nós, elite, é bom falar inglês, francês, português; para os outros não. Claro que isso tem a ver com os nossos tempos: acho que estamos assistindo a uma situação foucaulteana mesmo, onde há um discurso sobre diversidade sendo produzido e repetido. E há instituiçóes dedicadas à produção desse discurso que classicamente lembram a idéia da Microfísica do poder, ${ }^{11}$ sobretudo a Secretaria Especial de Políticas de Promoção da Igualdade Racial (SEPPIR). É um pequeno grupo, mas que está em todos os lugares, nos Municípios, nos Estados, em todos os Ministérios. Qualquer projetinho tem a máo dessa Secretaria, que produz e retroalimenta todo esse discurso, que se repete até nos lugares mais capilares da sociedade. De repente, a D. Zuleika acorda como uma quilombola. Antes ela não era, de repente ela é, assim como de repente a filha da D. Zuleika vai ter uma educação específica. Náo sei como será, como tampouco não sei o tipo de saúde específica que eles terão...

CC: Mas, ao mesmo tempo, o que faremos, já que é necessário o laudo antropológico para garantir o direito dessas populaçóes à terra?

PF: Esse é o grande paradoxo, exatamente. Uma amiga minha, Suzana Viegas, quando estava escrevendo sua tese de doutorado sobre os tupinambá, foi responsável pelo laudo de demarcação das terras desse grupo. Quer dizer que ela sabe o processo através do qual esse grupo indígena se nomeia o mais famoso da história do Brasil. Ela fez o laudo, pois se ques-

11. FOUCAULT, Michel. 1984. Microfísica do Poder. Rio de Janeiro: Graal. 
tionava: "Como é que vou deixar esse pessoal à margem do mundo?" Se eu tivesse que fazer, faria, mas sei perfeitamente que o meu laudo contrariaria tudo que estudei. Eu acho que isso é um problema muito sério, pois os antropólogos são chamados para fazer coisas que vêm a contrapelo da nossa disciplina. Afinal, na minha acepção, a antropologia moderna nasceu crítica em relação a esse tipo de pensamento, que demarca e essencializa fronteiras. Por isso, sempre incentivei, em Campinas e no Rio, que os alunos aproveitassem o espaço universitário para dizer o que não é dizível alhures, e as pessoas fazem isso bem. Isso é parte da tradição da disciplina e é muito legal... Nesse sentido, eu acho que Malinowski é um exemplo. Ele vivia da crítica das convençóes do seu tempo, questionando a universalidade da família monogâmica burguesa, por exemplo; isso era uma bomba para a época. As universidades são na verdade os únicos lugares de onde é possível falar... Mas os antropólogos estão numa situação complicada. Como é que podemos nos recusar a ajudar um grupo de pessoas, completamente sem terra e sem condições de sobrevivência, dessa oportunidade assegurar a sua segurança territorial? Só que esse direito passa por este caminho... Aí eu me pergunto, por que não lançar mão do usucapiáo? Não tem como? O usucapiáo se funda num direito que não discrimina raça, nem gênero, e além do mais produz o título individual, ao contrário dos quilombos, onde o título é coletivo. Acontece que os processos de usucapião simplesmente não andam! A reivindicaçáo de especificidade étnica tem conseqüências muito mais imediatas. Além disso, do ponto de vista da antropologia, é importante reconhecer que as palavras da própria disciplina entraram definitivamente para o cenário político. A questão da relatividade cultural virou assunto, assim como a idéia de alteridade, mas não uma alteridade como constatação analítica, e sim como um valor. Há uma série de discursos a produzir esses valores e a incitar práticas em relação a eles. Aliás, eu estou fascinado por isso, porque o Brasil se vê como misturado há anos, ensina às criancinhas que é misturado, e de repente ele não é mais misturado, é diverso! Essa pedagogia racial está sendo distribuída nas escolas para as crianças, e quem está dando as aulas? O Movimento $\mathrm{Ne}$ gro! Não é mais a sociedade brasileira e toda a sua complexidade que são apresentadas aos menininhos, é uma versão. Todo mundo acha que aquela Lei 10.639, que tornou obrigatória a inclusão na rede oficial de ensino a temática "História e cultura afro-brasileira" é fantástica, mas ninguém leu o parecer. Ele é de deixar o cabelo em pé. O governo continua, cada vez mais, com programas específicos para a população negra. Há uns meses, escrevi um artigo sobre a racialização da AIDS e ninguém respondeu. Imagino que isso produzirá situações muito interessantes de contradição, de confusão. Os mais otimistas acham que o Brasil é tão completamente misturado nesse sentido ideológico que, no fim das contas, tudo isso vai ser apenas uma nuvem passageira. Às vezes eu penso assim, outras vezes eu penso que náo, porque essa pedagogia racial nas escolas é algo sério. E quem passou pela África do Sul e viu tudo aquilo não pode ficar calado! Eles lutaram não sei quantos anos contra essa divisão de políticas públicas específicas, e sobretudo em educação. Que tipo de educação que se pode dar para um quilombola que é diferente da nossa? Isso significa algo, e foi o fato de as pessoas não discutirem estas questóes que me levou a juntar esses ensaios em um livro.

CC: Mas não se trata de políticas públicas que visam compensar situaçóes passadas de exclusão e segregação?

PF: Se fosse para o governo colocar a escola de Notre Dame no quilombo eu estaria de 
acordo. Mas não acredito que seja isso, duvido muito. Porque se houvesse uma política compensatória - que ninguém nunca fez - tinhase colocado, no Rio de Janeiro, as Escolas de Aplicação nas favelas. Quando o Brizola tentou fazer, durou pouco, os CIEP's foram exterminados. Dizem que também exterminaram essa experiência feita pelo governo Marta Suplicy, os CEU's. Eu acho essa uma idéia genial. Enfrenta-se a desigualdade fazendo, por exemplo, a melhor escola possível nos lugares mais pobres.

CC: Essas políticas não revelam um Estado liberal que nunca funcionou direito? Afinal, educação e saúde seriam direitos de todos...

PF: Seriam para todos e com a mesma qualidade. Porém, quando as pessoas dizem que as políticas universais nunca funcionaram, a solução que se pensa para esse problema é partir para as específicas. Mas ninguém nunca aplicou uma política universal, todo mundo sabe disso. Dessa maneira, eu acho interessante como uma sociedade imaginada como sociedade de classes se torna, de repente, uma sociedade de diversidade étnica e de gênero... É interessante que se trata do mesmo debate em relação às questóes de gênero. Eu tive conversas maravilhosas com o Roger Raupp Rios, que é Juiz Federal no Rio Grande do Sul e trabalha com legislação para direitos sexuais. É a mesma discussão porque, por um lado, há aqueles que querem dividir o mundo em identidades com legislação específica, e ele está tentando produzir uma legislação genérica, universal, em que caibam todas as possibilidades, não reprima nenhuma e não incite a repressão.

CC: Sobre esse ponto, como o senhor vê as possibilidades de comparação entre a questão racial e da sexualidade para compreendê-las no Brasil?
PF: Olhando para a sexualidade masculina, percebeu-se que havia uma complexidade nãovisível e comportamentos que, à primeira vista, são ambíguos. A descoberta disso foi a salvação do Brasil, pois se não tivesse percebido isso não se saberia como combater a AIDS. Quando se olha para a questão racial, a palavra que aparece muito também é "ambiguidade". Então, nos dois casos, a percepção de fronteiras não é muito clara; há essa questão em comum. Mas, diferentemente, a identidade homossexual que as organizaçóes construíram é positiva. Por exemplo, a Parada Gay é positiva e acolhedora - os resultados das pesquisas mostram que $20 \%$ das pessoas que estavam lá se diziam heterossexuais -, isto é, o movimento homossexual produziu assim uma identidade positiva e não-exclusiva. Seu símbolo, o arco-íris, é uma boa metáfora disso, porque se tem uma bandeira geral e debaixo dela há uma multiplicidade de possibilidades. Assim, politicamente, o movimento homossexual consegue colocar dois milhôes de pessoas na rua em São Paulo, e isso é muito significativo, pois todo mundo em um mesmo espaço implica em algum tipo de comunhão. Apesar de ainda ser uma categoria muito estigmatizada, mesmo assim se tem uma identidade positiva e um movimento que acolhe qualquer simpatizante. Agora, comparando com o outro lado, qual é a identidade que está sendo produzida sobre os negros no Brasil? É sobretudo uma identidade de vítima e um movimento que procura marcar diferença. Por isso, é um movimento que náo se expande, não aumenta; não é e nunca foi de massa, apesar de ser politicamente fortíssimo. O Ministério da Reforma Agrária, por exemplo, vai ter que titular não sei quantos quilombos em um ano... E cota é uma palavra que surge em 2001, literalmente. Como explicar que ela, desde então, se prolifera sozinha, sem precisar nem de legislação federal? 
CC: O senhor trabalha com as idéias de aparência e estética como importantes para a construção de uma imagem negra positiva, promovendo uma identidade não racializante. Em que medida é possível fazer essa discussão e implementar açôes anti-racistas e anti-racializantes na sociedade civil, fora do âmbito do Estado, a partir dessas categorias?

PF: Qualquer sociedade é feita a partir de uma leitura estética; os indivíduos são classificados assim. Para mim, parecia mais ou menos óbvio que qualquer ataque contra o racismo tinha que ser um ataque estético, e eu fiquei fascinado quando o mercado de bens higiênicos começou a se expandir e se diversificar para várias peles, cabelos etc. À medida que fui falando com os cabeleireiros, descobri que eles também ficavam fascinados, e que as pessoas que se sujeitavam a esse tipo de tratamento ficavam felizes. Antes, náo havia propaganda com mulher negra porque não havia produto para ela. Então, eu comecei a olhar para as propagandas desses novos produtos de uma forma distinta, porque achava que era uma maneira de se notar que algo estava mudando, e que uma estética antes esquecida tornava-se absolutamente visível. E isso corria a contragosto do próprio mercado, porque ele pouco se lixa para essas questóes de racismo; se interessa, evidentemente, pelo mercado de consumidores. Mas é o mercado que está efetivamente produzindo uma nova estética, e digo isso apenas a partir de uma reflexão muito superficial sobre a televisão mais popular, que é cada vez mais povoada por pessoas de estéticas diversas. Então, romanticamente, eu acho que é por aí que a coisa vai... $\mathrm{O}$ único lugar onde passou a existir cotas e que não me deixou arrepiado foi quando o governo do Município do Rio de Janeiro instituiu cotas para a propaganda pública. Eu achava a idéia interessante, porque náo colocava em evidência sempre as mesmas pessoas, e isso não ofende em nada porque obriga o reconhecimento da diversidade estética. Eu achei muito importante e penso que a publicidade brasileira poderia ser mais consciente disso. Por isso, quando eu escrevi esse artigo, não o fiz em tom de denúncia de propósito, não porque eu não fico chocado com o racismo, mas por ser uma maneira de falar com os produtores de propaganda. A idéia não foi colocá-los contra a parede, porque quando se coloca alguém contra a parede a tendência é que se fique ainda mais contra a parede, o adversário normalmente finca o pé. Isso acontece quando se produz um movimento muito agressivo, e é o que de certa maneira aconteceu com o Movimento Negro. Na minha opinião, ele agride ao acusar todo mundo de racista, pois as pessoas não se vêem como racistas; mesmo sendo, elas não se vêem assim.

CC: $\mathrm{O}$ seu livro termina com uma proposta de deslocar o debate em relação às políticas de ação afirmativa na Universidade de um foco de raça para o de classe social. Em que medida há limitaçóes nessas soluçóes que o senhor propóe - como a desterritorialização, a criação de um fundo de custeio para os estudos dos pobres, a reserva de vagas para estudantes de escolas públicas - já que são planos que não são discutidos pelo corpo acadêmico como um todo, além de trazerem, em graus diversos, dificuldades para a implementação?

PF: Eu acho que essa é a parte mais fraca do livro porque, no fundo, não vejo solução nenhuma a curto prazo. Eu penso que não há outra maneira de enfrentar essas questóes, senão um choque de educação e, nesse aspecto, o Brasil está anos-luz atrás de todo o mundo. Seria necessário mudar o sistema, pois finalmente se descobriu que o sistema educacional ibérico é feito para excluir. No Brasil, não se sai do Ensino Médio com um certificado sem ser aprovado em todas as matérias; na Inglaterra, sai-se graduado com as 
matérias em que se aprovou. Eu náo tenho uma visão muito clara sobre isso, mas sei que faria como Marta Suplicy fez, eu colocaria as melhores escolas e os melhores professores nos lugares mais pobres no Brasil. Se o programa dos CIEP's no Rio de Janeiro tivesse sido mantido de acordo com os princípios iniciais, teríamos hoje um contingente enorme de ex-pobres formados nas melhores universidades.

CC: Como o senhor avalia o espaço que o senhor conseguiu, como professor universitário, para influir no debate público em relação a todos esses temas?

PF: Eu sou absolutamente cético, infelizmente. Já escrevi e falo bastante sobre racialização e poucos me levam a sério (pelo menos em público). Então, não sei porque escrevo. Esse programa para a população negra de combate a AIDS é muito sério mesmo, e o que me espanta é que não há intelectuais negros também preocupados. Afinal, eles deveriam ficar receosos da racializaçáo indevida. E por quê? Porque toda política que leva à divisão entre brancos e negros no Brasil é apoiada automaticamente. É uma espécie de leninismo racial. Então, tornase necessário fazer um programa de AIDS para a população negra sabendo perfeitamente que é uma questáo de classe, que não tem nada a ver com raça. E isso é loucura porque estamos construindo cegamente aquilo que os outros países de tradição racializadora gostariam de desconstruir. Eu náo acredito que o Tarso Genro pensou nisso quando mudou de um dia para o outro e disse: "Era contra cotas e agora sou a favor". Náo acredito que ele tenha ponderado que há uma reafirmaçáo da categoria raça que é implícita à política de cotas. Isso é muito espantoso porque ele pertence à esquerda do PT, que sempre pensou em termos de classe social e que, de repente, passou a apoiar uma política compensatória para as "etnias" que, aliás, virou uma espécie de metáfora para classe. Desse jeito, cria-se uma espécie de sofisma, fala-se que “os negros são pobres, a maioria dos pobres são negros; entáo, nós esquecemos os pobres e falamos que a AIDS está aumentando entre os negros, quando teríamos que falar entre os negros e os brancos pobres". Exclui-se os brancos e racializa-se a discussão. $\mathrm{O}$ rumo planejado por essa política parece ser apenas fortalecer as organizaçóes negras da sociedade civil. Mas antes de tomar esse rumo, acho que o Brasil tinha que se discutir como nação e não como um movimento. Fico numa posição absolutamente incômoda lutando contra os pressupostos da maioria dos ativistas negros; não gosto de parecer contrário a essa luta, é muito desagradável. Mas é uma convicção, e essa é a convicção que funda a antropologia moderna que vem desde Franz Boas, que dissociou raça de cultura, e pronto. 